\title{
Distribution of Rickettsia rickettsii in ovary cells of Rhipicephalus sanguineus (Latreille1806) (Acari: Ixodidae)
}

\author{
Luís Flávio da Silva Costa ${ }^{1 \dagger}$, Pablo Henrique Nunes ${ }^{1 \dagger}$, João Fábio Soares ${ }^{2 \dagger}$, Marcelo Bahia Labruna ${ }^{2 \dagger}$ and \\ Maria Izabel Camargo-Mathias ${ }^{1 *}$
}

\begin{abstract}
Background: Considering the fact that the dog tick, Rhipicephalus sanguineus, has a great potential to become the vector of Brazilian Spotted Fever (BSF) for humans, the present study aimed to describe the distribution of the bacterium Rickettsia rickettsii, the etiological agent of BSF, in different regions of the ovaries of $R$. sanguineus using histological techniques. The ovaries were obtained from positive females confirmed by the hemolymph test and fed in the nymph stage on guinea pigs inoculated with $R$. rickettsii.

Results: The results showed a general distribution of $R$. rickettsii in the ovary cells, being found in oocytes in all stages of development (I, II, III, IV and V) most commonly in the periphery of the oocyte and also in the cytoplasm of pedicel cells.

Conclusions: The histological analysis of the ovaries of $R$. sanguineus infected females confirmed the presence of the bacterium, indicating that the infection can interfere negatively in the process of reproduction of the ticks, once alterations were detected both in the shape and cell structure of the oocytes which contained bacteria.
\end{abstract}

Keywords: Rickettsia rickettsii, Rhipicephalus sanguineus, Brazilian Spotted Fever, ovary, histology

\section{Background}

Rickettsia rickettsii, the etiological agent of Brazilian Spotted Fever (BSF) in Brazil and Rocky Mountain Spotted Fever in the United States [1] is an obligatory intracellular gram-negative bacterium which survives for a short time out of the host [2], being transmitted to humans and other animals by different species of ticks. These organisms are usually 0.8 to $2 \mu \mathrm{m}$ long, with a diameter of 0.3 to $0.5 \mu \mathrm{m}$ [3] and having a cellular wall formed by peptidoglycan and lipopolysaccharides [4]. The infection caused by rikettsiae is systemic in ticks as they multiply in the cytoplasm of the intestine, ovaries, salivary glands, Malpighian tubules cells and are also found in the hemolymph of the ectoparasite [5]. Following infection of the ovaries, transstadial and transovarial transmission of the pathogen can happen [6].

\footnotetext{
* Correspondence: micm@rc.unesp.br

+ Contributed equally

'Departamento de Biologia, Instituto de Biociências UNESP - Rio Claro/SP, Brasil

Full list of author information is available at the end of the article
}

Rickettsia rickettsii is considered the most pathogenic species of rickettsia, being reported in Canada, United State, Mexico, Costa Rica, Panama, Brazil, Colombia and Argentina [7]. Many ticks are known as vectors of $R$. rickettsia in the world. In Brazil the known vectors are Amblyomma cajennense, tick vector in most of the endemic areas in the country and A. aureolatum, responsible for the transmission in some metropolitan areas of São Paulo [8,9]. Recent studies point to R. sanguineus as a possible vector of $R$. rickettsii for humans in some regions of Brazil. Moraes-Filho et al. [10] reported the presence of $R$. sanguineus positive for $R$. rickettsii in the metropolitan region of São Paulo and Cunha et al. [11] reported the same for Rio de Janeiro state and Pacheco et al. [12] in Juiz de Fora, Minas Gerais. Although $R$. sanguineus has not been confirmed as vector of spotted fever for humans in Brazil, it has been confirmed as a vector in the USA and Mexico [13] and has also been considered as a possible vector in Colombia [5]. Dantas-Torres et al. [14] and Louly et al. [15]
C Biomed Central

(ㄷ) 2011 da Silva Costa et al; licensee BioMed Central Ltd. This is an Open Access article distributed under the terms of the Creative Commons Attribution License (http://creativecommons.org/licenses/by/2.0), which permits unrestricted use, distribution, and reproduction in any medium, provided the original work is properly cited. 
reported human parasitism by $R$. sanguineus in the brazilian states of Pernambuco and Goiás, reinforcing the hypothesis that this tick can become a vector of $R$. rickettsii for humans in Brazil.

The $R$. sanguineus tick is originally from Africa and is commonly known as the "brown dog tick", with a wide geographic distribution [16]. This species was introduced into the urban environment by the domestic dog, which is considered its main host [17]. It is important to emphasize that $R$. sanguineus is the only species of tick that is considered an "urban plague" as it parasitizes dogs in urban and rural areas [18].

The ovary of the tick is located in the posterior third of the body, having a horseshoe shaped. The ovary of $R$. sanguineus is histologically classified as panoistic, with the lumen delimited by a delicate wall of small epithelial cells where the oocytes are fixed by the pedicel in all phases of development (stages I to V) [19].

Considering these facts, the aim of this study was to analyze through histological techniques the distribution of the bacterium $R$. rickettsii in the ovaries of fully-fed and semi-engorged $R$. sanguineus females, contributing to a better knowledge about the interaction between $R$. rickettsii and ticks in general.

\section{Results}

\section{Confirmation of infection by $R$. rickettsii}

In the first infestation (feeding of the nymphs), on the fifth day after the inoculation of the homogenate containing the bacterium, the guinea pigs presented with fever (temperature $>40^{\circ} \mathrm{C}$ ) and one of them presented with a scrotal lesion and died on the ninth day. The animals of the control group did not present with a temperature increase during the whole infestation.

In the second infestation (feeding of adults) the three guinea pigs infested by adult ticks from the infected group of the first phase presented with fever (temperature $>40^{\circ} \mathrm{C}$ ) and one of them presented with a scrotal lesion and died on the ninth day. The individuals of the control group did not present with a temperature increase during the whole infestation.

For the confirmation of infection in $R$. sanguineus females, a hemolymph test [20] was followed, where all the tested females of the control group presented hemocytes with normal morphology (Figure 1A) and the females of the infected group presented hemocytes with the cytoplasm filled with several bacteria (strongly stained) (Figure 1B). PCR showed that ten females from the control group did not react to the test and of ten females from the infected group, nine were positive in the test, confirming the infection by R. rickettsii.

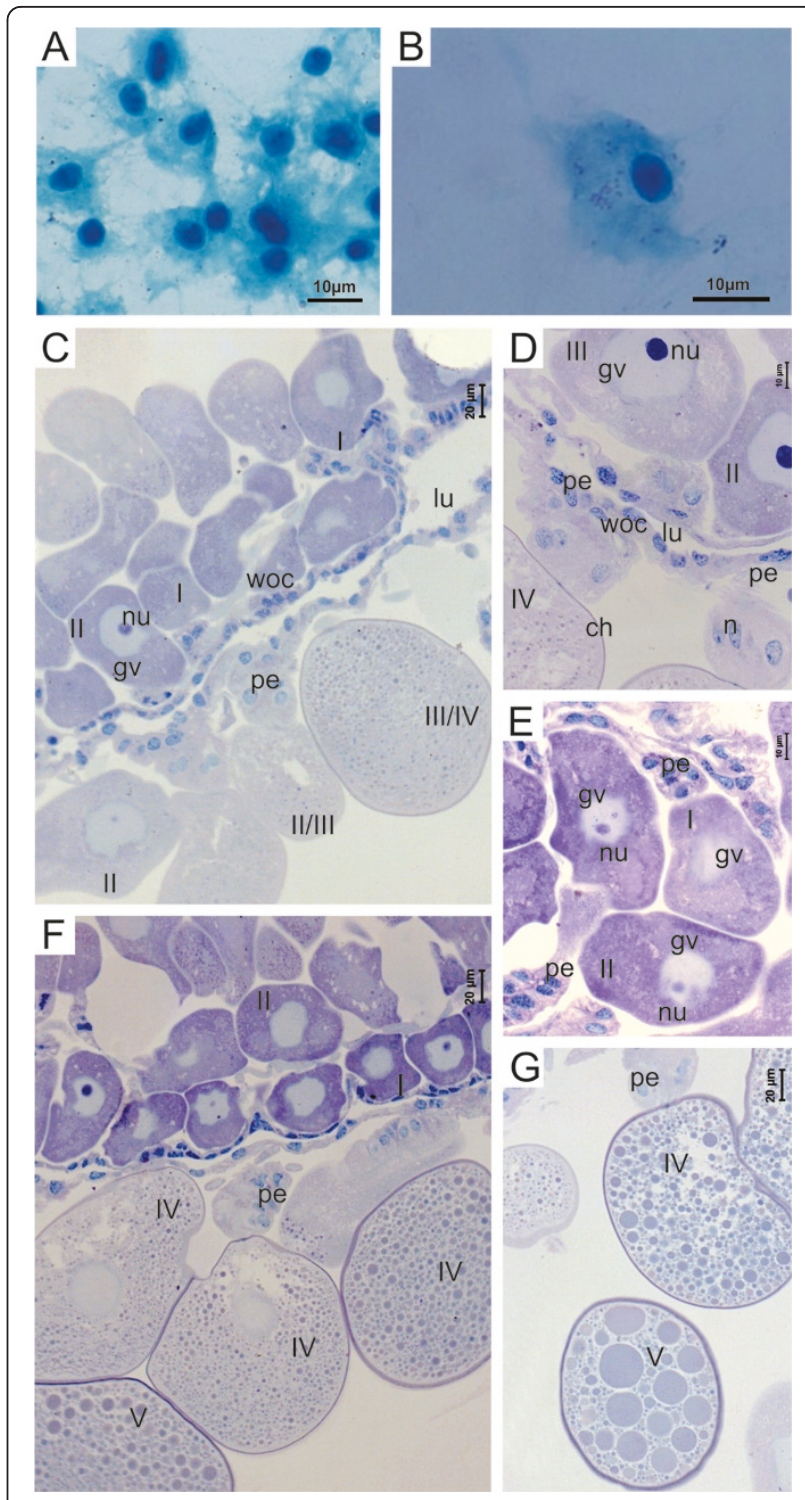

Figure 1 Hemolymph cells and histological sections of Rhipicephalus sanguineus oocytes of control group. (A) hemocytes with normal morphology stained using the Gimenez technique [28]. (B) Hemocyte with the presence of R. rickettsii stained using the Gimenez technique [28]. C, D, E, F and G, detail of oocytes in all stages of development (I, II, III, IV and V) using Giemsa staining. Ch, choriun; gv, germinal vesicle; lu, lumen; nu, nucleus; $p$, pedicel; woc, ovary wall cells.

\section{Histology of the ovaries in the Control Group}

The ovaries of the females of the control group did not present any morphological variation, having as reference the pattern established by Oliveira et al. [19] in the first description of $R$. sanguineus ovary. Oocytes in several stages of development can be observed (Figure 1C-G), in addition to the pedicel cells connecting each oocyte to the ovary wall (Figure 1C-G). 


\section{Histology of the ovaries in the Infected Group}

The ovaries of the semi-engorged infected females contained oocytes in all stages of development. Although $R$. rickettsii has been detected in the oocytes in all stages of development they are more frequently found in the oocytes II and III (Figure 2A, B, D and 2F) and are most commonly located in the periphery of the oocyte (Figure $2 \mathrm{~A}-\mathrm{F}$ ). It was also observed that the highest concentration of bacteria is located in the pole of the oocyte adjacent to the pedicel cells (Figure 2B and 2D), which were also colonized by the bacteria, although with fewer bacteria than found in the oocytes. Many oocytes with altered morphology were observed (Figure $2 \mathrm{C}$ and $2 \mathrm{~F}$ ) in contrast to oocytes from the control group. No $R$. rickettsii were observed in the cells of the ovary's wall.

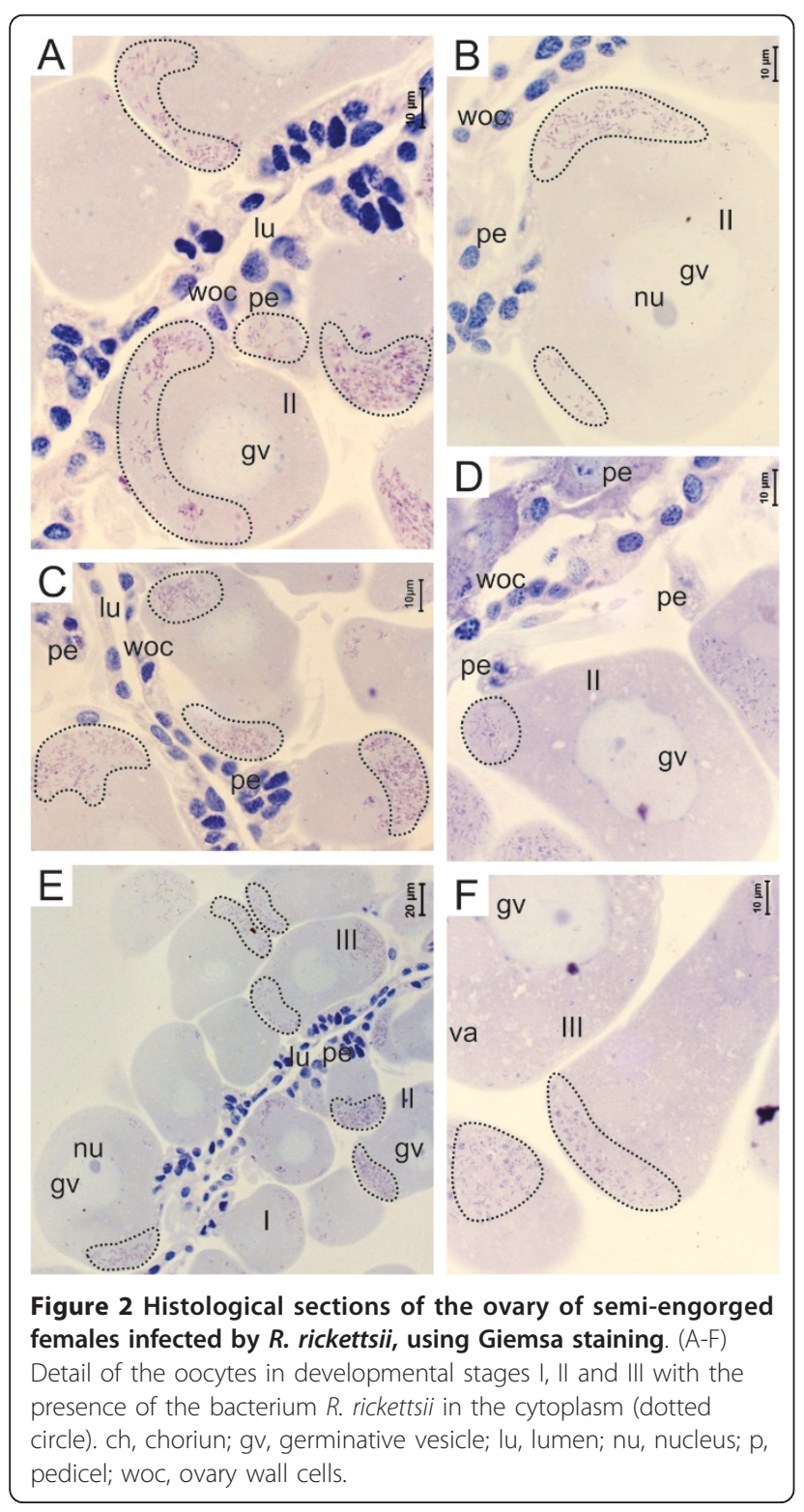

Oocytes in the five stages of development were identified in the ovaries of engorged females (Figure 3 and 4). Infection by $R$. rickettsii was observed in the oocytes in all the stages of development (Figure 3B, 4B-D). The distribution of $R$. rickettsii in the oocytes was not homogeneous; in the semi-engorged females, groups of bacteria are most commonly located in the periphery of the oocytes (Figure 3A, $4 \mathrm{C}, \mathrm{D}$ and $4 \mathrm{~F}$ ). In some cases bacteria are grouped around the germinal vesicle (Figure $3 \mathrm{~A}$ and $4 \mathrm{E}$ ).

The pedicel cells are also parasitized by $R$. rickettsia in semi-engorged and engorged females; with fewer numbers of bacteria in the cells of semi-engorged females (Figure 3A-E, 4C-D). As with the semi-engorged females, in engorged females the cells of the ovary wall were not infected with $R$. rickettsii.

\section{Discussion}

The present study brings morphological data of the occurrence of transstadial and transovarial transmission of $R$.

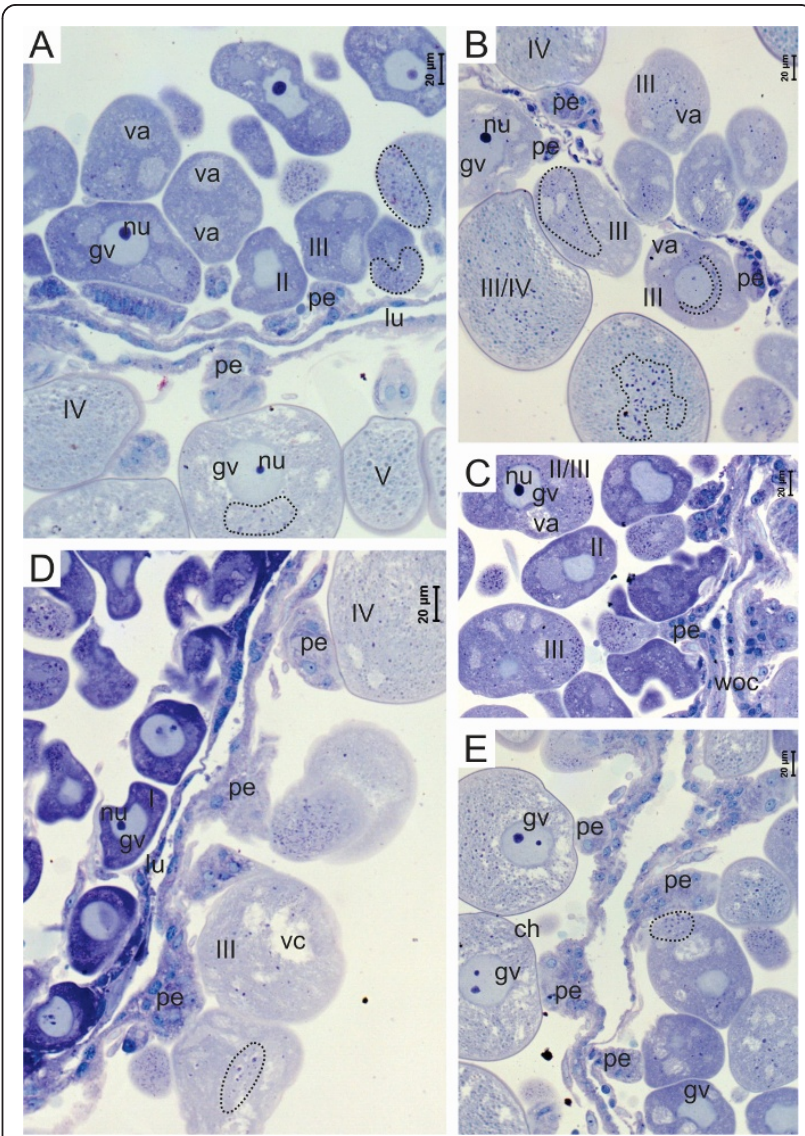

Figure 3 Histological sections of the ovary of engorged females infected by $R$. rickettsia, stained using Giemsa. (A-E) Detail of oocytes in all the stages of development with the presence of the bacterium $R$. rickettsii in the cytoplasm (dotted circle). ch, chorion; gv, germinal vesicle; lu, lumen; nu, nucleus; $p$, pedicel; woc, ovarian wall cells. 


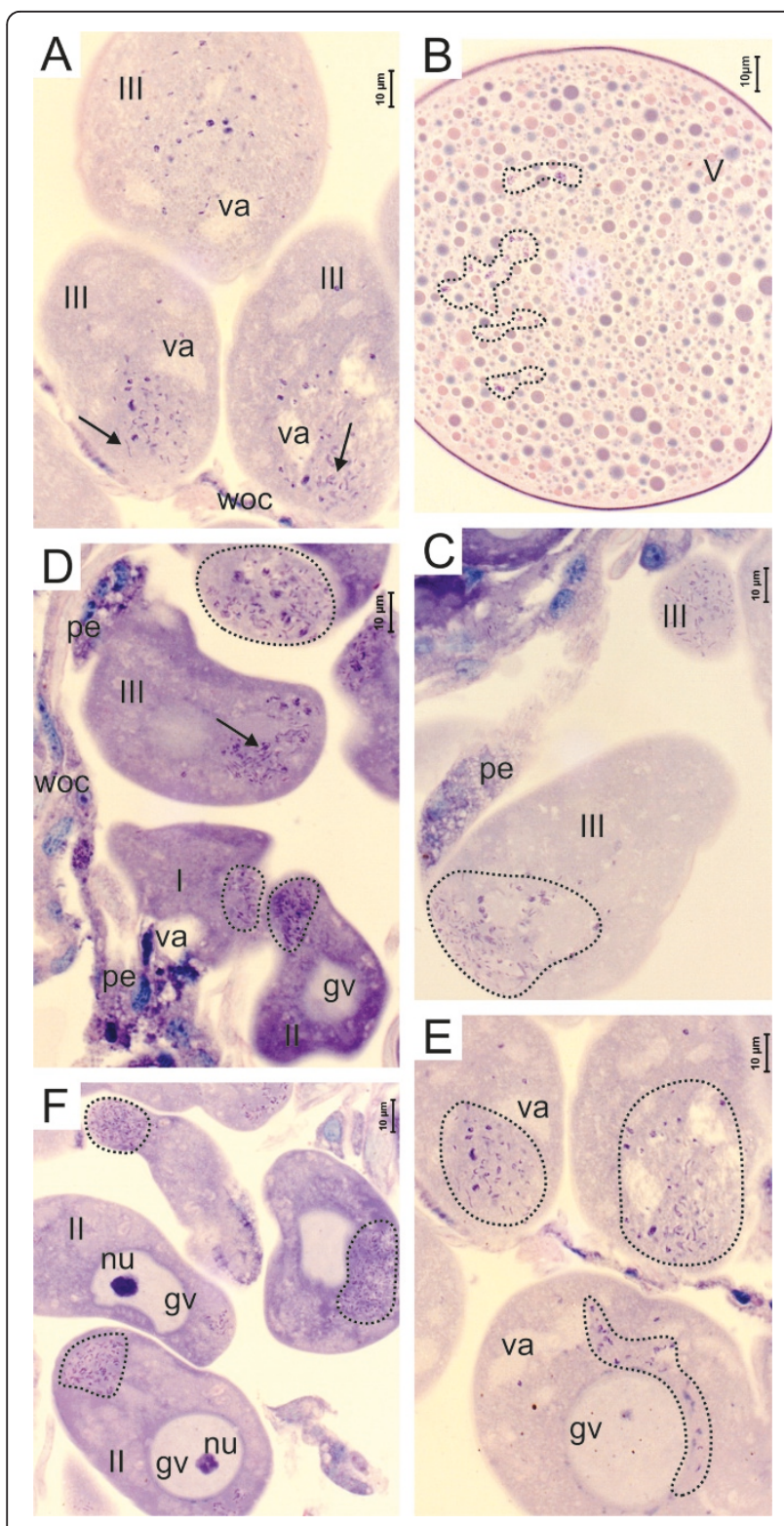

Figure 4 Histological sections of a Giemsa-stained ovary of an engorged female infected by $\boldsymbol{R}$. rickettsii. (A-E) Detail of the oocytes in all development stages with the presence of the bacterium $R$. rickettsii in the cytoplasm (dotted circle). (B) Detail of the oocyte $V$ with $R$. rickettsia in its interior. ch, choriun; $g v$, germinative vesicle; lu, lumen; nu, nucleus; p, pedicel; woc, ovary wall cells; arrow, bacterium $R$. rickettsia.

rickettsii in the $\operatorname{dog}$ tick $R$. sanguineus through histological analysis of the ovaries of semi-engorged and fully engorged females. The analysis of the results demonstrated that the infection provoked in the guinea pigs by adult $R$. sanguineus caused characteristic signs of BSF, as demonstrated by Mancini et al. [21], i.e., the animals presented temperature equal or higher than $40^{\circ} \mathrm{C}$, in addition to scrotal lesion, with death of one individual. These results demonstrate the effective transstadial transmission in $R$. sanguineus when infected in the phase of nymph, corroborating the results obtained by Parker et al. [22] and Piranda et al. [23]. According to Burgdorfer \& Brinton [24], the successful transovarial transmission depends primarily on the degree of rickettsial development in ovaries tissues. In this study $R$. rickettsii was observed in the oocytes in almost all of the stages of development, both in semi-engorged and in fully engorged females, corroborating Burgdorfer [25] and, Burgdorfer and Brinton [24] studying in the tick Dermacentor andersoni. Furthermore, Piranda et al. [23] using a PCR technique reported the transovarial transmission of $R$. rickettsii in $R$. sanguineus, also infected in nymph phase

The histological analysis of the ovaries of $R$. sanguineus infected females confirmed the presence of the bacterium, and indicated that the infection can interfere negatively in the process of reproduction of the ticks, as alterations were detected both in the shape and in the cell structure of the oocytes, which contained bacteria mainly in the fully engorged females - the ones that would be ready for oviposition. This supports the theory of Macdade and Newhouse [26], which postulates that the relationship between $R$. rickettsii and ticks is not always of perfect symbiosis; i.e., in some cases the microorganisms could harm the tick's organs causing damage to threaten its survival. Therefore, the fact that the oocytes of $R$. sanguineus infected by $R$. rickettsii show morphological alterations could suggest that the bacterium, in addition to being harmful for the host, could also be harmful to the reproductive process of the infected females.

The preferred distribution of $R$. rickettsii in the oocyte cytoplasm was at the oocyte pole in direct contact with the pedicel cells. Its presence in these cells and its absence from the ovary wall cells could suggest that, in addition to the hemolymph, the bacteria use the pedicel cells as a route of entry to the oocytes environment. This may occur when the cells of the pedicel transfer lipid, protein and polysaccharide material to the interior of the oocytes, helping in the production of yolk [19]. The pedicel cells are in turn infected by the bacteria from the hemolymph, from where they extract material to be used in vitellogenesis.

\section{Conclusions}

Studying the relationship between ticks and pathogens has been very important to understand the mechanisms of infection and transmission of these pathogens, as well as to elaborate efficient strategies to avoid the diseases caused by them. Therefore, the present study clearly demonstrated that the transstadial transmission of $R$. rickettsii in $R$. sanguineus is efficient when these are infected in the phase of nymph. Although there is transovarial transmission in the females derived from these infected nymphs, the bacteria interfere negatively in the 
reproductive process by altering the morphology of the oocytes.

\section{Methods}

Adult females of $R$. sanguineus infected with $R$. rickettsii were used in this study, which was performed in the Laboratory of Parasitary Diseases of the Department of Preventive Veterinary Medicine and Animal Health VPS, Veterinary Medicine and Zootechny College of USP - University of Sao Paulo, SP, Brazil, under the supervision of Prof. Dr. Marcelo Bahia Labruna.

Two phases of infestation were necessary for the experiment, in accordance to Piranda et al. [23]. In the first phase, six guinea pigs were divided in two groups, the control group with three individuals $(\mathrm{C} 1, \mathrm{C} 2, \mathrm{C} 3)$ and the infected group also with three individuals (I1, I2, I3). In each guinea pig of the infected group a $3 \mathrm{~mL}$ solution containing brains ( $\left.\mathrm{n}^{\circ}: 7 / 9 / 2009\right)$ and liver $\left(\mathrm{n}^{\circ}\right.$ : 1-16/03/09) of guinea pigs positive for $R$. rickettsii and brain-heart infusion (BHI) was inoculated intraperitoneally after asepsis in the abdominal region according to the protocol described by Labruna et al. [8]. The temperature of the guinea pigs was measured daily during the whole feeding period in order to confirm the infection. After the feeding period the fully engorged nymphs were placed in a biochemical oxygen demand (BOD) incubator at $27^{\circ} \mathrm{C}$, remaining there for 48 days. During this period the nymphs completed ecdysis, reaching the adult phase.

In the second phase of infection, six other guinea pigs were used, being divided into two groups (control and infected). The individuals from the control group were infested by adult $R$. sanguineus from the control groups of the first feeding period, while the individuals from the infected group were infested by $R$. sanguineus adults from the infected group of the first feeding period. As in the first phase, the temperature of the guinea pigs was measured daily for confirmation of infection.

\section{Analysis of the ticks}

Females of $R$. sanguineus, which had fed for 5 days and the fully engorged females were prepared for the hemolymph test to confirm the infection and the ovaries were removed to be processed for histology. Ten females from the control group and 10 from the infected group were kept in a freezer at $-20^{\circ} \mathrm{C}$, for the extraction of DNA and performance of PCR according to the protocol described by Labruna et al. [27], for the confirmation of infection by $R$. rickettsii.

\section{Hemolymph test}

The performance of the test followed the protocol described by Burgdorfer [20], where the distal portion of one of the front legs of the ticks was cut with scissors and one or two drops of hemolymph were placed onto a glass slide previously cleaned and de-greased. The slides were then fixed at room temperature, stained by the method of Gimenez [28] and examined and photographed using a Leica photomicroscope, in the Histology Laboratory of the Biology Department of the Biosciences Institute of UNESP campus Rio Claro (SP), Brazil.

\section{Histological technique}

For the performance of histological techniques the ovaries were removed and fixed in $4 \%$ paraformaldehyde and in $10 \%$ neutral-buffered formaldehyde solution $(\mathrm{pH} 7-$ 7.4) and acetone in the proportion 9:1 for 1 hour at room temperature and for 30 minutes at $4^{\circ} \mathrm{C}$. The material was then dehydrated in increasing concentrations of ethanol (70\%, 80\%, 90\% and 95\%), for 15 minutes each, transferred to embedding resin and sectioned with a microtome in $3 \mu \mathrm{m}$-thick sections, which were collected on glass slides, rehydrated in distilled water for 1 minute and stained with solution containing Giemsa (8 g), Glycerol $(500 \mathrm{~mL}$ ) and Methanol (buffered pH 6.8, 1000 $\mathrm{mL})$, dissolved in a buffered solution of $\mathrm{NaOH} 4$ (1:50), for 40 minutes, and washed in buffer. After drying, the slides were diaphanized in xylol, mounted in synthetic Canada balsam and covered with a coverslip. The material was observed and photographed using a Leica photomicroscope in the Histology Laboratory of the Biology Department of the Biosciences Institute of UNESP campus Rio Claro (SP), Brazil.

\section{Acknowledgements}

Gerson Mello Souza and Ms. Alexandro Santana Vieira for technical support and CAPES for financial support.

\section{Author details}

'Departamento de Biologia, Instituto de Biociências UNESP - Rio Claro/SP, Brasil. ${ }^{2}$ Laboratório de Doenças Parasitárias do Departamento de Medicina Veterinária Preventiva e Saúde Animal - VPS, USP - São Paulo, Brasil.

\section{Authors' contributions}

LFSC and JFS performed the infection of ticks with R. rickettsii, LFSC and $\mathrm{PHN}$ performed the histological analysis and wrote the manuscript, MBL and MICM supervised the research and the writing of the manuscript. All authors approved the final, version of the manuscript.

\section{Competing interests}

The authors declare that they have no competing interests.

Received: 15 September 2011 Accepted: 25 November 2011 Published: 25 November 2011

\section{References}

1. Melles HHB, Colombo S, Lemos ERS: Isolamento de Rickettsia em cultura de células Vero. Rev Soc Bras Med Trop 1999, 32(Suppl 5):469-473.

2. Vranjac A: Informe Técnico Sobre a Febre Maculosa Brasileira. Secretaria de Estado da Saúde Coordenação dos Institutos de Pesquisa Divisão de Zoonoses, São Paulo 2002. 
3. La Scola B, Raoult D: Laboratory diagnosis of rickettsioses: current approaches to diagnosis of old and new rickettsial diseases. J clin microbiol 1997, 35(Suppl 11):2715-2727.

4. Mcdade JE: Rickettsial diseases. In Microbiology and Microbial Infections.. 9 edition. Edited by: Hausler Jr WJ, Sussman M. London: Topley and Wilson's; 1998:995-1011.

5. Silva ME: Frequência De Anticorpos Anti-Rickettsia Spp Em Cães Da Cidade De Belo Horizonte. Dissertação de mestrado apresentada à Universidade Federal de Minas Gerais UFMG, Faculdade de Veterinária de Belo Horizonte 2007.

6. Cardoso LD: Detecção e caracterização da Rickettsia spp circulante em foco inativo periurbano do município de Caratinga, MG. Dissertação de Mestrado apresentada à Universidade Federal de Ouro Preto, Núcleo de Pesquisa em Ciências Biológicas Programa de Pós-graduação em Ciências Biológicas 2004.

7. Labruna MB: Ecology of Rickettsia in South America. In Rickettsiology and Rickettsial Diseases-Fifth International Conference. Volume 1166. Edited by: Hechmy KE, Samuel JE, Brouqui P, Raoult DA. Annals of the New York Academy of Sciences: May 2009; New York; 2009:156-166.

8. Labruna MB, Ogrzewalska M, Martins TF, Pinter A, Horta MC: Comparative Susceptibility of Larval Stages of Amblyomma aureolatum, Amblyomma cajennense, and Rhipicephalus sanguineus to Infection by Rickettsia rickettsii. J med entomol 2008, 45(Suppl 6):1156-1159.

9. Pinter A, Labruna MB: Isolation of Rickettsia rickettsii and Rickettsia bellii in cell culture from the tick Amblyomma aureolatum in Brazil. Ann NY Acad Sci 2006, 1078:523-529.

10. Moraes-Filho J, Pinter A, Pacheco RC, Gutmann TB, Barbosa SO, Gonzáles MARM, Cecílio SRM, Labruna MB: New Epidemiological Data on Brazilian Spotted Fever in an Endemic Area of the State of São Paulo, Brazil. Vector Borne Zoonotic Dis 2009, 9(Suppl 1):73-78.

11. Cunha NC, Fonseca AH, Rezende J, Rozental T, Favacho ARM, Barreira JD, Massard CL, Lemos ERS: First identification of natural infection of Rickettsia rickettsii in the Rhipicephalus sanguineus tick, in the State of Rio de Janeiro. Pesqui Vet Bras 2009, 29(Suppl 2):105-108.

12. Pacheco RC, Moraes-Filho J, Guedes E, Silveira I, Richtzenhain LJ, Leite RC, Labruna MB: Rickettsial Infections of Dogs, Horses and Ticks In Juiz de Fora, Southeastern Brazil, and Isolation of Rickettsia rickettsii from Rhipicephalus sanguineus Ticks. Med vet entomol 2011, 25:148-155.

13. Demma LJ, Traeger MS, Nicholson WL, Paddock DR, Blau DM, Eremeeva ME, Dasch GA, Levin MJ, Singleton J Jr, Zaki SR, Cheek JE, Swerdlow DL, Mcquiston JH: Rocky Mountain Spotted Fever from an Unexpected Tick Vector in Arizona. N Engl J Med 2005, 353(Suppl 6):587-594.

14. Dantas-Torres F, Figueredo LA, Brandão-Filho SP: Rhipicephalus sanguineus (Acari: Ixodidae), The Brown Dog Tick, Parasitizing Humans in Brazil. Rev So Bras Med Trop 2006, 39(Suppl 1):64-67.

15. Louly CCB, Fonseca IN, Oliveira VF, Borges LMF: Ocorrência de Rhipicephalus sanguineus em Trabalhadores de Clínicas Veterinárias e Canis, no Município de Goiânia, GO. Ci Anim Bras 2006, 7(Suppl 1):103-106.

16. Pegram RG, Clifford CM, Walker JB, Keirans JE: Classification of the Rhipicephalus sanguineus, Rhipicephalus sulcatus and Rhipicephalus turanicus. Syst Parasitol 1987, 10:3-26.

17. Sexton DJ, Burgdorfer W, Thomas L: Rocky Mountain spotted fever in Mississipi: survey for spotted fever antibodies in dogs and for spotted fever group Rickettsial in dog ticks. Am J Epidemiol 1976, 103:192-197.

18. Labruna MB, Pereira MC: Carrapatos em cães no Brasil. Clin Vet 2001, 30:24-32.

19. Oliveira PR, Bechara GH, Denardi SE, Saito KC, Nunes ET, CamargoMathias MI: Morphological characterization of the ovary and oocytes vitellogenesis of the tick Rhipicephalus sanguineus (Latreille, 1806) (Acari: Ixodidae). Exp Parasitol 2005, 110:146-156

20. Burgdorfer W: The hemolymph test. Am J Trop Med Hyg 1970, 19:1010-1014.

21. Mancini DAP, Nascimento EMM, Tavares VR, Soares MA: A ocorrência de riquetsioses do gruporickettsia rickettsii. Rev Saúde Púb/ 1983, 17:493-499.

22. Parker R, Philip CB, Jellinson WL: Rocky Mountain spotted fever. Potentialities of tick transmission in relation to geographic occurrence in the United States. Am J Trop Med 1933, 13:241-378.

23. Piranda EM, Faccini JLH, Pinter A, Pacheco RC, Cançado PHD, Labruna MB: Experimental Infection of Rhipicephalus sanguineus Ticks with the
Bacterium Rickettsia rickettsii, Using Experimentally Infected Dogs. Vector Borne Zoonotic Dis 2011, 11(Suppl 1):29-35.

24. Burgdorfer W, Brinton LP: Mechanisms of transovarial infec-tion of spotted fever rickettsiae in ticks. Ann N Y Acad Sci 1975, 266:61-72

25. Burgdorfer W: Investigation of "Transovarial Transmission" of Rickettsia rickettsii in the Wood Tick, Dermacentor andersoni. Exp Parasitol 1963, 14:152-159.

26. Mcdade JE, Newhouse VF: Natural History of Rickettsia rickettsii. Ann Rev Microbiol 1986, 40:287-309.

27. Labruna MB, Whitworth T, Horta MC, Bouyer DH, Mcbride JW, Pinter A, Popov V, Gennari SM, Walker DH: Rickettsia species infecting Amblyomma cooperi ticks from an area in state of São Paulo, Brazil, where Brazilian spotted fever is endemic. J clin microbiol 2004, 42:90-98.

28. Giménez DF: Staining rickettsiae in yolk sacs cultures. Stain Technol 1964, 39:135-140.

doi:10.1186/1756-3305-4-222

Cite this article as: da Silva Costa et al:: Distribution of Rickettsia rickettsii in ovary cells of Rhipicephalus sanguineus (Latreille1806)

(Acari: Ixodidae). Parasites \& Vectors 2011 4:222.

\section{Submit your next manuscript to BioMed Central and take full advantage of:}

- Convenient online submission

- Thorough peer review

- No space constraints or color figure charges

- Immediate publication on acceptance

- Inclusion in PubMed, CAS, Scopus and Google Scholar

- Research which is freely available for redistribution

Submit your manuscript at www.biomedcentral.com/submit
C) Biomed Central 